CATALLAXY

Volume 4 Issue 2 December 2019

e-ISSN 2544-090X

$\triangle$ www.catallaxy.pl

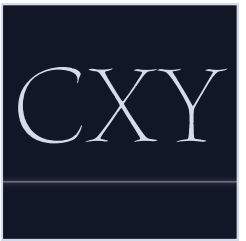

Oryginalny artykut naukowy

otrzymano: 27.06.2019 / zaakceptowano: 02.09.2019 / opublikowano online: 03.09.2019

Pukin, P. (2019). Wplyw wprowadzenia euro na handel państw czlonkowskich unii monetarnej. Catallaxy, 4(2):

113-122. doi:10.24136/cxy.2019.007.

\title{
Wpływ wprowadzenia euro na handel państw członkowskich unii monetarnej
}

\section{PAULINA PUKIN}

Uniwersytet Warminsko-Mazurski w Olsztynie, Wydziat Nauk Ekonomicznych, Katedra Makroekonomii, ul. Prawocheńskiego 10/202, 10-719 Olsztyn, Polska

曰ppukin@outlook.com

(D) orcid.org/0000-0002-2162-079X

\begin{abstract}
Abstrakt
Motywacja: Zgodnie z nową teorią optymalnego obszaru walutowego, ujednolicenie waluty powinno przyczynić się do zwiększenia powiązań gospodarczych państw członkowskich. W literaturze przedmiotu efekt kreacji handlu, powstały w wyniku wprowadzenia euro, nazywany jest efektem euro. Mimo, że istnieje bardzo dużo opracowań na temat tego efektu oraz wielu związanych z nim aspektów, trudno jest jednoznacznie ustalić jego rozmiar, zwłaszcza dla państw Europy Srodkowej i Wschodniej, które w latach 2007-2015 wprowadziły euro.

Cel: Celem artykułu jest zaprezentowanie zestawienia badań ekonomistów specjalizujących się w badaniach dotyczących efektu euro oraz wyników własnej analizy statystycznej.

Materiały i metody: Wykorzystano krytyczną analizę literatury przedmiotu, zarówno polskojęzycznej, jak i zagranicznej oraz analizę statystyczną, opartą na danych Banku Światowego.

Wyniki: Efekt euro niewątpliwie występuje, jednak trudno jednoznacznie określić jego rozmiar. Jego wielkość jest zróżnicowana pod względem sektorowym. Ponadto, można zauważyć zróżnicowany wpływ wprowadzenia euro na handel poszczególnych państw członkowskich unii walutowej, który zależny jest od kilku czynników, tj. momentu wprowadzenia euro, wielkości rynku, otwartości gospodarczej państw i specjalizacji oraz rozdrobnienia produkcji poszczególnych gospodarek.
\end{abstract}

Stowa kluczowe: euro; strefa euro; handel; efekt euro

JEL: F14; F15

1. Wprowadzenie

Zgodnie $z$ egzogenicznym podejściem do teorii optymalnych obszarów walutowych (TOOW), wysoka otwartość gospodarcza jest jednym $z$ kryteriów umożliwiających absorpcję szoków makroekonomicznych w unii walutowej (McKinnon, 1963, ss. 717-725). Na skutek kryzysu gospodarczego okazało się jednak, że państwa o dużym wolumenie han- dlu dóbr i usług z państwami ze strefy euro (niezależnie od używanej waluty) są zagrożone wystąpieniem wahań koniunkturalnych oraz bardzo wysokim zadłużeniem i deficytem sald obrotów bieżących (Obstfeld i Rogoff, 2009).

Nowe podejście do teorii optymalnych obszarów walutowych wprowadzono i przyjęto pod koniec XX wieku. Jej głównymi twórcami byli Frankel i Rose (1998). Autorzy dokonali istotnej analizy konsekwencji wprowadze- 
nia wspólnej waluty w Europie. Według nich, najważniejszą korzyścią, wynikającą z ujednolicenia waluty jest zmniejszenie kosztów transakcyjnych. Autorzy uznali utratę autonomii polityki monetarnej za największe zagrożenie utworzenia strefy euro. Najważniejszy jednak wkład Frankela i Roséa (1998) do TOOW dotyczył wpływu integracji monetarnej na wzrost zbieżności cykli koniunkturalnych oraz wzrostu wymiany handlowej wynikającej $z$ utworzenia unii monetarnej.

Frankel i Rose (1998) potwierdzili swoją tezę badaniami empirycznymi. Ich analiza opierała się na określeniu korelacji między powiązaniami gospodarczymi a cyklami koniunkturalnymi dwudziestu jeden rozwiniętych państw w latach 1959-1993. Rose również $\mathrm{w}$ późniejszym czasie próbował określić potencjalny wpływ wprowadzenia euro na handel wewnątrz ugrupowania. Glick i Rose (2002) dostrzegli, że między państwami, które wykorzystują wspólną walutę, wytwarza się dodatkowy strumień przepływu dóbr, który nazwano „efektem Rose'a”. Autor stwierdzil, że podobny związek przyczynowo-skutkowy wystąpi w strefie euro („efekt euro” lub „efekt handlowy euro").

Analiza Glicka i Roséa (2002) krytykowana jest przez wielu badaczy. Ekonomiści dostrzegają niepoprawnie dobrany obiekt badań. Krytycy uznali, że większość państw przez nich badanych charakteryzowała się niewielką i słabo rozwiniętą gospodarką. Natomiast państwa, które utworzyły strefę euro, charakteryzują się wysokim wzrostem społeczno-gospodarczym (Cindea i Cindea, 2012, ss. 1267-1272). Pozostali ekonomiści krytykują narzędzia ekonometryczne, które Glick i Rose (2002) wykorzystali w badaniu. Tenreyro (2007) uznał, że model grawitacyjny, który jest wykorzystany najczęściej do zmierzenia efektu euro, jest niepoprawny z kilku przyczyn (np. nieuwzględnienie par państw, dla których bilateralny eksport wynosi zero).

W sekcji 2. dokonano przeglądu literatury przedmiotu. W sekcji 3. opisano wykorzystane materiały i metody. W sekcji 4. przedstawiono otrzymane wyniki, natomiast $\mathrm{w}$ sekcji
5. zawarto podsumowanie przeprowadzonej analizy.

\section{Przegląd literatury}

Wielu ekonomistów (m.in. Baldwin i in., 2008; Berger i Nitsch, 2008; Bun i Klassens, 2007; De Nardis i in., 2008; Flam i Nordstorm, 2006; Fontange i in., 2009; Havranek, 2010; Micco i in., 2003) próbowało określić rzeczywisty wpływ ujednolicenia waluty na handel wewnątrz ugrupowania. Wyniki badań, na skutek wykorzystywania zróżnicowanych metod badawczych oraz zakresu badań, wskazały na zróżnicowaną skalę efektu euro.

W literaturze przedmiotu można odnaleźć dwa najistotniejsze zestawienia badań na temat efektu euro (Baldwin i in., 2008; Havranek, 2010). Havranek (2010) zaprezentował w swojej metaanalizie ponad sześćdziesiąt opracowań (w tym dwadzieścia osiem dotyczących konkretnie strefy euro). Autor zaobserwowal, że różnice $w$ rozmiarach efektu euro wynikają z kilku czynników. Pierwszą determinantą był obiekt badań. Havranek (2010) zauważył, że oszacowanie efektu euro powinno być oparte jedynie o dane statystyczne dotyczące państw członkowskich strefy euro. Jest to bardzo ważne ze względu na ich specyfikę.

Ekonomista wspomina także o tzw. problemie publication bias. Pojawia się on w przypadku badań nad rozmiarem efektu euro. Autor zauważył, że wzrost zainteresowania tematem przyczynił się do pojawienia się wielu opracowań o niskim poziomie naukowości, z których wynika zawyżony rozmiar efektu euro. Można zauważyć, że publikacje w czasopismach o niskim impact factor przedstawiają zawyżony rozmiar efektu euro. Havranek (2010) dostrzegł także, że opracowania, których autorem lub współautorem był Rose wykazywały wyższy efekt niż przykładowo w przypadku badań Baldwina i in. (2008).

Zestawienie Baldwina i in. (2008), wskazuje na zróżnicowanie pod względem obiektu i zakresu badań, a także na dywersyfikację wyników wynikającą $z$ wcześniej wymienionych różnic opracowań oraz wykorzystanej 
metodyki badań (tabela 1.). Można zauważyć, że większość autorów wskazuje na niewielki efekt handlowy euro wewnątrz ugrupowania.

$Z$ dwóch opracowań wynika jednak, że rozmiar efektu euro może wynieść od 6 do 20\%. Baldwin i in. (2008) oraz Flam i Nordstorm (2006) spróbowali także określić wpływ wprowadzenia euro na handel $z$ państwami trzecimi. $Z$ pierwszego opracowania wynika, $\dot{z} e$ ujednolicenie waluty $w$ Europie przyczyniło się do przesunięcia handlu i zmniejszenia konkurencyjności państw trzecich, wskutek czego zanotowano spadek eksportu do innych państw. Według Flama i Nordstorma (2006) istnieje jednak bardzo niewielki pozytywny wpływ $(0,8 \%)$ wprowadzenia euro na handel $z$ państwami trzecimi.

Jedno $z$ najważniejszych badań na temat wpływu wprowadzenia euro na handel poszczególnych sektorów i gospodarek zostało przygotowane przez De Nardisa i in. (2008). Analiza efektu euro na poszczególne sektory wskazała, że wpływ wprowadzenia euro na większość branż jest znikomy. Według autorów, znaczenie ujednolicenia waluty przyczyniło się do rozwoju przedsiębiorstw $z$ branż, w których występuje duże znaczenie krańcowych kosztów produkcji.

Wyniki ich badań nie wykazały wpływu ujednolicenia waluty $w$ większości państw w poszczególnych sektorach. Liczba sektorów zyskujących na ujednoliceniu waluty w żadnym państwie nie przekraczała ośmiu. Najwyższą notę uzyskano w przypadku Hiszpanii (osiem sektorów), Holandii (pięć sektorów), Austrii, Grecji, Niemiec (po cztery sektory), Belgii (trzy sektory), Portugalii, Włoch, Francji (dwa sektory), a dla Finlandii nie uzyskano żadnego pozytywnego efektu. W tym państwie zanotowano największą liczbę sektorów (siedem), w których ujednolicenie waluty przyczyniło się do zmniejszenia konkurencyjności. Drugim państwem o wysokim negatywnym wpływie wprowadzenia euro na handel, była Francja (sześć sektorów). W pozostałych państwach zanotowano zerowy lub niewielki negatywny efekt na handel sektorowy.

\section{Materiały i metody}

W artykule wykorzystano krytyczną analizę literatury przedmiotu zarówno polskojęzycznej, jak i zagranicznej oraz analizę statystyczną opartą na danych Banku Światowego (2019).

Pierwszą wymienioną metodą jest analiza źródeł naukowych. Realizację badań zainicjowały studia literaturowe w oparciu o krajowe i zagraniczne publikacje naukowe podejmujące problematykę wpływu wprowadzenia euro na handel w strefie euro.

Analiza danych statystycznych umożliwiła określenie kilku istotnych aspektów handlu międzynarodowego państw EU-25 (otwartość gospodarcza, najważniejsi partnerzy eksportowi, rozmiar wymiany handlowej). Podstawę części empirycznej stanowiły dane Banku Światowego (2019).

W celu określenia wpływu wprowadzenia euro na handel poszczególnych państw, państwa członkowskie UE podzielono na tzw. stare i nowe państwa ugrupowania.

\section{Wyniki badania}

Otwartość gospodarcza państw członkowskich strefy euro była zróżnicowana (tabela 2.). Do państw EU-15 o najwyższym poziomie wskaźnika otwartości gospodarczej, rozumianej jako stosunek eksportu i importu do PKB, można zaliczyć: Luksemburg (182,87\% w 1990 roku i 382,29\% w 2014 roku), Irlandię $(104,90 \%$ w 1990 roku i 208,17\% w 2014 roku), Holandię (104,57\% w 1990 roku i 154,29\% w 2014 roku), Belgię (120,57\% w 1990 roku i $164,71 \%$ w 2014 roku) oraz Austrię (71,48\% w 1990 roku i 103,54\% w 2014 roku). Niższy odnotowany poziom wskaźnika otwartości (mieszczący się w przedziale 60$85 \%)$ był jednak dość wysoki. Warto jednak zauważyć, że w państwach o niższej otwartości gospodarczej występuje ponadprzeciętny wolumen handlu (np. w Niemczech). Wyniki potwierdzają tezę Wincenciaka (2014) o wysokiej otwartości gospodarczej niewielkich gospodarek. 
W Unii Europejskiej (UE) występowało zróżnicowanie państw pod względem otwartości gospodarczej (tabela 3.). Państwa o najwyższej otwartości to przede wszystkim: Malta, Cypr oraz Estonia. Natomiast Polska w 1997 roku charakteryzowała się względnie niską otwartością gospodarczą w porównaniu do innych państw.

W analizowanym okresie w wielu państwach otwartość gospodarcza zwiększyła się, przy czym największa zmiana wystąpiła w takich państwach, jak: Polska (wzrost o $107,15 \%$ ), Czechy (wzrost o 78,58\%), Słowenia (wzrost o 60,67\%), Litwa i Słowacja (wzrost po ok. 59\%), Węgry (wzrost o 57,57\%). Natomiast w przypadku państw o najwyzszym stopniu otwartości gospodarczej, można zauważyć niewielki, kilkuprocentowy (3-4\%), spadek poziomu tego wskaźnika. Wyniki analizy statystycznej wskazują na brak zależności między wpływem wprowadzenia euro a wzrostem otwartości gospodarczej państw unijnych.

Wydaje się jednak, że McKinnon (1963) miał przede wszystkim na myśli otwartość gospodarczą wobec państw, z którymi dane państwo wspóltworzy unię walutową. Pozytywną obserwacją jest to, że państwa członkowskie UE przynależące do strefy euro są dla siebie ważnymi partnerami handlowymi. Znaczenie poszczególnych państw jako partnerów handlowych dla większości państw członkowskich determinowane jest: znaczeniem państwa $\mathrm{w}$ światowej gospodarce oraz położeniem geograficznym. Niemcy oraz Francja byli najistotniejszymi partnerami dla wszystkich państw EU-15. Ważnymi partnerami handlowymi ze strefy euro byli: Włochy, Holandia oraz Hiszpania, natomiast spoza unii monetarnej: Wielka Brytania oraz Stany Zjednoczone.

W latach 1997-2017 w niewielkim stopniu zmieniła się lista najważniejszych partnerów handlowych wybranych państw (tabela 4. i tabela 5.). Struktura najważniejszych partnerów eksportowych państw, które przystąpiły do UE w 2004 roku i wprowadziły euro w latach 2007-2015, różni się od list państw tzw. starej UE. Dywersyfikacja najistotniejszych partnerów wymienionych państw wynika z kilku czynników: położenia geopolitycznego, historii gospodarczej, polityki ekonomicznej oraz przede wszystkim tego, czy dane państwo należało do Związek Socjalistycznych Republik Radzieckic (ZSRR). Mimo, że ZSRR przestał istnieć w 1992 roku, jego członkowie zarówno w 1997 roku, jak i 2017 roku należeli do najważniejszych partnerów handlowych państw bałtyckich. Cypr charakteryzował się odmienną listą najważniejszych partnerów eksportowych. Powiązania gospodarcze Cypru ukształtowane były głównie przez położenie geograficzne oraz politykę gospodarczą. Malta, Słowacja oraz Słowenia posiadały najbardziej zbliżoną strukturę partnerów eksportowych do EU-15. Niemcy byli głównym partnerem eksportowym państw Europy Środkowo-Wschodniej. Dla państw, które przystąpily do strefy euro $\mathrm{w}$ latach 2007-2015, ważnymi partnerami była także Austria, Francja oraz Włochy.

Wprowadzenie euro mogło mieć jedynie niewielki wpływ na zmianę najważniejszych partnerów eksportowych w latach 1997-2017. Wśród najważniejszych partnerów analizowanych państw nie pojawil się członek strefy euro niewymieniony w 1997 roku. Co ciekawe, trudno nawet byłoby stwierdzić, że przystąpienie do UE przyczyniło się na zmianę partnerów eksportowych danych państw.

Następną analizowaną kwestią był wzrost handlu w latach 2002-2012 w porównaniu ze zmianą handlu poszczególnych państw w latach 1992-2002 (wykres 1.). Można zauważyć, że prawie we wszystkich państwach EU-15 zmiana handlu w późniejszym analizowanym okresie była kilkakrotnie wyższa od wcześniejszego. Inna sytuacja wystąpiła w przypadku Finlandii oraz Irlandii, gdzie, mimo wzrostu handlu, odnotowano niższą dynamikę zmian. Najwyższy wzrost handlu w latach 2002-2012 zaobserwowano w: Luksemburgu (215,19\%), Niemczech (140,62\%), Holandii (135,93\%), Austrii (128,52\%), Grecji $(127,76 \%)$, Szwecji $(126,80 \%)$, Portugalii (125,59\%), Belgii $(125,14 \%)$, natomiast najniższy: we Włoszech (91,18\%), we Francji (90,51\%), w Wielkiej Brytanii $(89,65 \%)$ oraz Finlandii $(85,81 \%)$. 
$\mathrm{Na}$ podstawie analizy zmiany eksportu w nowych państwach członkowskich w latach 2004-2016, można zauważyć bardzo dużą synchronizację cyklu handlowego oraz bardzo wysoki wzrost wolumenu eksportu we wszystkich analizowanych państwach (wykres 2.). Można wyróżnić cztery grupy państw pod względem dynamiki wzrostu eksportu. W przypadku pierwszej z nich, wynosiła ona od ok. 150\%. Należały do niej: Litwa (196,95\%), Łotwa (195,72\%), Polska (181,84\%), Estonia (150,88\%) oraz Malta (148\%). Drugą grupę stanowiły państwa o przeciętnej dynamice eksportu: Czechy $(127,15 \%)$ i Słowacja (113,60\%). W trzeciej grupie znalazły się państwa o poniżej przeciętnej dynamice wzrostu eksportu: Węgry $(82,49 \%)$ oraz Słowenia $(83,24 \%)$. Do czwartej grupy, o najniższej dynamice wzrostu eksportu, zaklasyfikowano jedynie Cypr $(33,96 \%)$.

\section{Zakończenie}

Wielu twórców teorii optymalnych obszarów walutowych zakłada, że rozmiar oraz struktura handlowa państw tworzących unię monetarną jest bardzo istotna. Przykładowo, McKinnon (1963) uznał, że otwartość handlowa jest bardzo ważnym kryterium optymalizacji. Trudno jest jednak ustalić czy strefa euro spełnia to kryterium ze względu na brak jednoznacznie określonej wartości referencyjnej. Niewątpliwie ujednolicenie waluty powinno przyczynić się do wzrostu handlu wewnątrz ugrupowania oraz możliwe, że również z państwami trzecimi.

Rose uznał, że wprowadzenie euro przyczyni się do kilkukrotnego wzrostu handlu w strefie euro. Większość ekonomistów uważa jednak, że efekt handlowy euro wynosi kilka, maksymalnie kilkanaście procent. Ponadto, można zauważyć zróżnicowany wpływ wprowadzenia euro na handel poszczególnych państw członkowskich unii walutowej.

Wyniki przeprowadzonej analizy wskazują na wysokie zróżnicowanie państw strefy euro pod względem otwartości gospodarczej, struktury najważniejszych partnerów eksportowych i importowych, a także zmiany wolumenu eksportu. Dywersyfikacja państw wynika $z$ kilku przyczyn: przystąpienia (lub nie) do strefy euro, momentu wprowadzenia euro, wielkości gospodarki, polityki gospodarczej, położenia geopolitycznego oraz zależności od ZSRR w przeszłości.

Państwa $z$ derogacją, takie przykładowo Polska, powinny zastanowić się nad wprowadzeniem wspólnej waluty pod względem potencjalnego wpływu euro na handel, uwzględniając otwartość gospodarczą oraz doświadczenia zarówno starych, jak i nowych państw członkowskich strefy euro.

\section{Bibliografia}

Baldwin, R., DiNino, V., Fontange, L., De Santis, R.A., i Taglioni, D. (2008). Study on the impact of the euro on trade and foreign direct investment. Economic Papers, 321. doi:10.2765/65274.

Bank Światowy. (2019). Pobrane 01.09.2019 z https://data.worldbank.org.

Berger, H., i Nitsch, V. (2008). Zooming out: the trade effect of the euro in historical perspective. Journal of International Money and Finance, 27(8). doi:10.1016/j.jimonfin.2008.07.005.

Bun, M., i Klaassen, F. (2002). Has the euro increased trade? Tinbergen Institute Discussion Paper, 108(2). doi:10.2139/ssrn.338602.

Cindea, I.M., i Cindea, M. (2012). The euro effect on international trade. Procedia: Social and Behavioral Sciences, 58. doi:10.1016/j. sbspro.2012.09.1109.

De Nardis, S., De Santis, R., i Vicarelli, C. (2008). The single currency's effects on Eurozone sectoral trade: winners and losers? Economics: The Open-Access, Open-Assessment E-Journal, 2. doi:10.5018/economics-ejournal.ja.2008-17.

Flam, H., i Nordstrom H. (2006). Trade volume effects of the euro: aggregate and sector estimates. Seminar Papers, 746.

Fontange, L., Mayer, T., i Ottaviano, G.I.P. (2009). Of markets, products, prices: the effects of the euro on Europen firms. Intereconomics, 44(3). doi:10.1007/s10272-009-0289-8.

Frankel, J.A., \& Rose, A.K. (1998). The endogenity of the optimum currency area criteria. The Economic Journal, 108(449). doi:10.1111/1468-0297.00327.

Glick, R., i Rose, A.K. (2002). Does a currency union affect trade? The time-series evidence. European Economic Review, 46(6). doi:10.1016/ s0014-2921(01)00202-1. 
Havranek, T. (2010). Rose effect and the euro: is the magic gone? Review of World Economics, 146(2). doi:10.1007/s10290-010-0050-1.

McKinnon, R.I. (1963). Optimum currency areas. The American Economic Review, 53(4).

Micco, A., Stein, E., i Ordonez, G. (2003). The currency union effect on trade: early evidence from EMU. Economic Policy, 18(37). doi:10.1111/1468-0327.00109_1.

Obstfeld, M., i Rogoff, K. (2009). Global imbalances and the financial crisis: products of common causes. CEPR Discussion Papers, 7606.

Tenreyro, S. (2007). On the trade impact of nominal exchange rate volatility. Journal of Development Economics, 82 (2). doi:10.1016/j. jdeveco.2006.03.007.
Wincenciak, L. (2014). European Monetary Union in the light of optimum currency areas theory. W: K. Opolski, i J. Górski (red.), Perspektywy $i$ wyzwania integracji europejskiej. Warszawa: Uniwersytet Warszawski.

Informacje uzupetniające

Wkład autorski: autor zaakceptował ostateczną wersję artykułu.

Źródła finansowania: artykuł został w całości sfinansowany ze środków własnych autora.

Uwagi: wyniki badania byly zaprezentowane na 9. Ogólnopolskiej Konferencji Naukowej Problemy gospodarki światowej (10 maja 2019, Toruń). 
Aneks

Tabela 1 .

Zestawienie badań na temat efektu euro

\begin{tabular}{lccc}
\hline \multicolumn{1}{c}{ Autor } & $\begin{array}{c}\text { Efekt kreacji handlut } \\
(\mathrm{w} \%)\end{array}$ & $\begin{array}{c}\text { Eksport ze strefy euro do państw trzecich } \\
(\mathrm{w} \%)\end{array}$ & Analizowany okres \\
\hline Baldwin i in. (2008) & 2,0 & $-1,0 \%$ & $1996-2002$ \\
Berger i Nitsch (2008) & 0,0 & - & $1948-2002$ \\
Bun i Klassens (2007) & 3,0 & - & $1967-2002$ \\
Flam i Nordstorm (2003) & 8,8 & $0,8 \%$ & $1980-2002$ \\
Micco i in. (2003) & $6,0-20,0$ & - & $1980-2002,1992-2002$ \\
\hline
\end{tabular}

Żródło: Fontange i in. (2009).

Tabela 2.

Otwartość gospodarcza państw EU-15 w latach 1990-2014 (w \%)

\begin{tabular}{lrrrr}
\hline \multicolumn{1}{c}{ Państwo } & 1990 & 2002 & 2014 & Zmiana 1990-2014 \\
\hline Austria & 71,49 & 86,95 & 103,53 & 44,82 \\
Belgia & 120,57 & 135,12 & 164,71 & 36,61 \\
Finlandia & 45,82 & 69,29 & 75,37 & 64,49 \\
Francja & 42,74 & 53,07 & 60,48 & 41,51 \\
Grecja & 40,13 & 50,35 & 67,15 & 67,33 \\
Hiszpania & 35,64 & 54,98 & 63,00 & 76,77 \\
Holandia & 104,57 & 114,71 & 154,29 & 47,55 \\
Irlandia & 104,90 & 163,77 & 208,17 & 98,44 \\
Luksemburg & 182,87 & 258,84 & 382,29 & 109,05 \\
Niemcy & 46,01 & 60,77 & 84,49 & 83,64 \\
Portugalia & 65,05 & 62,16 & 79,96 & 22,91 \\
Włochy & 36,43 & 48,20 & 55,76 & 53,06 \\
Dania & 67,29 & 84,56 & 102,26 & 51,97 \\
Szwecja & 56,86 & 77,86 & 85,66 & 50,65 \\
Wielka Brytania & 47,02 & 50,34 & 58,03 & 23,42 \\
\hline
\end{tabular}

Źródło: Opracowanie własne na podstawie danych Banku Światowego (2019). 
Tabela 3.

Otwartość gospodarcza państw EU-10 w latach 1997-2017 (w \%)

\begin{tabular}{|c|c|c|c|c|}
\hline Państwo & 1997 & 2007 & 2017 & Zmiana 1997-2017 \\
\hline Cypr & 139,76 & 111,27 & 133,57 & $-4,43$ \\
\hline Czechy & 85,07 & 130,37 & 151,93 & 78,58 \\
\hline Estonia & 153,68 & 135,27 & 148,53 & $-3,35$ \\
\hline Litwa & 100,01 & 113,84 & 159,02 & 59,00 \\
\hline Łotwa & 88,47 & 95,92 & 122,10 & 38,01 \\
\hline Malta & 226,11 & 258,51 & 249,20 & 10,21 \\
\hline Polska & 50,47 & 80,66 & 104,56 & 107,15 \\
\hline Stowacja & 119,54 & 167,67 & 190,68 & 59,51 \\
\hline Stowenia & 96,33 & 136,49 & 154,76 & 60,67 \\
\hline Węgry & 107,21 & 158,21 & 168,93 & 57,57 \\
\hline
\end{tabular}

Źródło: Opracowanie własne na podstawie danych Banku Światowego (2019).

Tabela 4.

Najważniejsi partnerzy eksportowi państw UE-15 w 1997 i 2017 roku

\begin{tabular}{|c|c|c|}
\hline Państwo & Najważniejsi partnerzy w 1997 roku & Najważniejsi partnerzy w 2017 roku \\
\hline Austria & $\begin{array}{l}\text { Niemcy, Włochy, Szwajcaria, Węgry, Wielka } \\
\text { Brytania }\end{array}$ & Niemcy, USA, Włochy, Szwajcaria, Francja \\
\hline Belgia & $\begin{array}{l}\text { Francja, Niemcy, Holandia, Wielka Brytania, } \\
\text { Włochy ( } 1999 \text { rok) }\end{array}$ & $\begin{array}{l}\text { Niemcy, Francja, Holandia, Wielka Brytania, } \\
\text { Włochy }\end{array}$ \\
\hline Niemcy & Francja, USA, Wielka Brytania, Włochy, Holandia & USA, Francja, Chiny, Wielka Brytania, Holandia \\
\hline Hiszpania & $\begin{array}{l}\text { Francja, Niemcy, Włochy, Portugalia, Wielka } \\
\text { Brytania }\end{array}$ & $\begin{array}{l}\text { Francja, Niemcy, Włochy, Portugalia, Wielka } \\
\text { Brytania }\end{array}$ \\
\hline Finlandia & Niemcy, Wielka Brytania, Szwecja, Rosja, USA & Niemcy, Szwecja, Holandia, USA, Rosja \\
\hline Francja & $\begin{array}{l}\text { Niemcy, Wielka Brytania, Włochy, Hiszpania, } \\
\text { Belgia-Luksemburg }\end{array}$ & Niemcy, Hiszpania, Włochy, USA, Belgia \\
\hline Grecja & Niemcy, Włochy, Wielka Brytania, USA, Francja & Włochy, Niemcy, Turcja, Cypr, Bułgaria \\
\hline Irlandia & Wielka Brytania, Niemcy, USA, Francja, Holandia & USA, Wielka Brytania, Belgia, Niemcy, Szwajcaria \\
\hline Włochy & Niemcy, Francja, USA, Wielka Brytania, Hiszpania & Niemcy, Francja, USA, Hiszpania, Wielka Brytania \\
\hline Luksemburg & $\begin{array}{l}\text { Niemcy, Francja, Belgia, Wielka Brytania, Włochy } \\
\text { (1999 rok) }\end{array}$ & Niemcy, Francja, Belgia, Holandia, Włochy \\
\hline Holandia & $\begin{array}{l}\text { Niemcy, Belgia-Luksemburg, Francja, Wielka } \\
\text { Brytania, Włochy }\end{array}$ & Niemcy, Belgia, Wielka Brytania, Franja, USA \\
\hline Portugalia & $\begin{array}{l}\text { Niemcy, Hiszpania, Francja, Wielka Brytania, } \\
\text { Holandia }\end{array}$ & Hiszpania, Francja, Niemcy, Wielka Brytania, USA \\
\hline
\end{tabular}

Źródło: Opracowanie własne na podstawie danych Banku Światowego (2019). 
Tabela 5.

Najważniejsi partnerzy eksportowi państw UE-7 w 1997 i 2017 roku

\begin{tabular}{lll}
\hline \multicolumn{1}{c}{ Państwo } & \multicolumn{1}{c}{ Najważniejsi partnerzy w 1997 roku } & \multicolumn{1}{c}{ Najważniejsi partnerzy w 2017 roku } \\
\hline Cypr & $\begin{array}{l}\text { Rosja, Wielka Brytania, Bułgaria, Grecja, Zjedno- } \\
\text { czone Emiraty Arabskie }\end{array}$ & Libia, Bunkers, Grecja, Norwegia, Wielka Brytania \\
Estonia & Rosja, Finlandia, Szwecja, Łotwa, Litwa & Finlandia, Szwecja, Rosja, Łotwa, Niemcy \\
Litwa & Rosja, Niemcy, Białoruś, Ukraina, Dania & Rosja, Łotwa, Polska, Niemcy, USA \\
Łotwa & Rosja, Wielka Brytania, Niemcy, Szwecja, Litwa & Litwa, Estonia, Rosja, Niemcy, Szwecja \\
Malta & Francja, USA, Niemcy, Singapur, Wielka Brytania & USA, Bunkers, Niemcy, Egipt, Francja (2016 rok) \\
Słowacja & Czechy, Niemcy, Austria, Włochy, Polska & Niemcy, Czechy, Polska, Francja, Węgry \\
Słowenia & Niemcy, Włochy, Chorwacja, Austria, Francja & Niemcy, Włochy, Chorwacja, Austria, Francja \\
\hline
\end{tabular}

Źródło: Opracowanie własne na podstawie danych Banku Światowego (2019).

\section{Wykres 1.}

Zmiana eksportu w państwach EU-15 w latach 1992-2012 (w mld USD)

2000

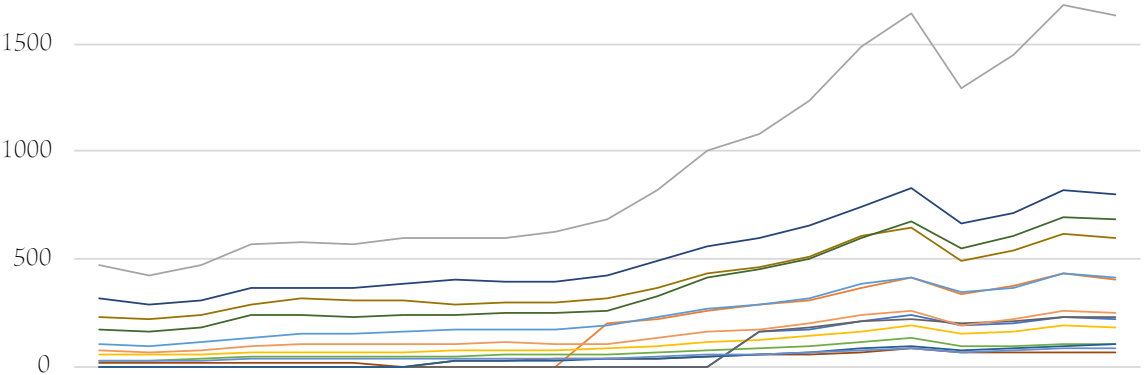

199219931994199519961997199819992000200120022003200420052006200720082009201020112012

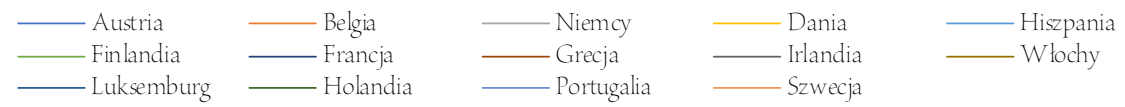

Źródło: Opracowanie własne na podstawie danych Banku Światowego (2019). 


\title{
Wykres 2.
}

\section{Zmiana eksportu w państwach, które przystąpiły do UE w 2004 roku w latach 2004-2016 (w mld USD)}

300

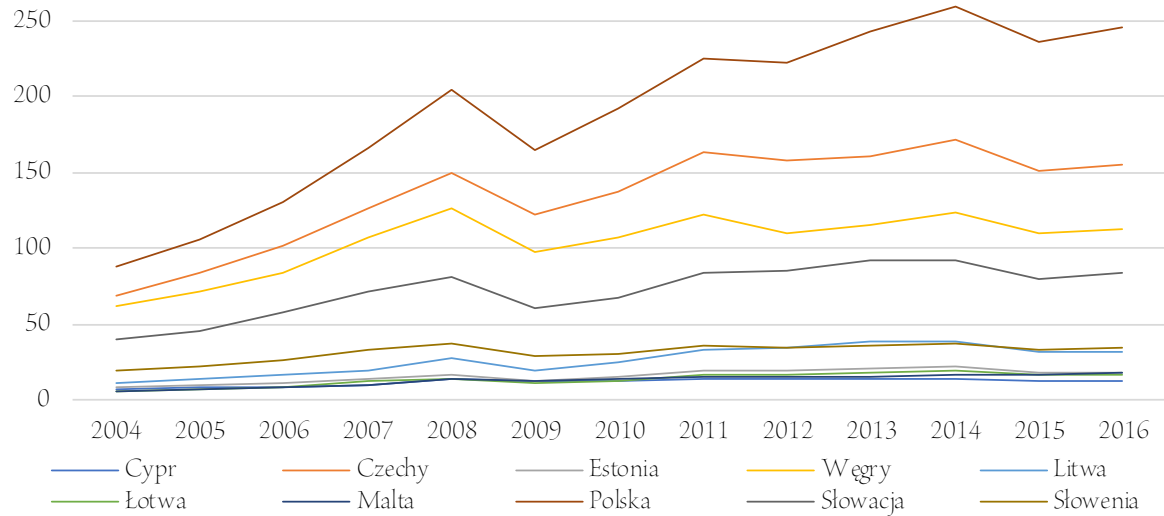

Źródło: Opracowanie własne na podstawie danych Banku Światowego (2019).

The impact of the euro introduction on the trade in the monetary union member states

\begin{abstract}
Motivation: According to the new theory of the optimal currency area, the unification of the currency should contribute to increasing the economic ties of the Member States. In the literature on the subject, the effect of trade creation, resulting from the introduction of the euro, is called the euro effect. Although there are a lot of studies on this effect and many aspects related to it, it is difficult to clearly determine its size, especially for the countries of Central and Eastern Europe that introduced the euro in 2007-2015.

Aim: The aim of the article is to present a list of studies of economists specializing in research on the euro effect and the results of own statistical analysis.

Materials and methods: A critical analysis of the literature on the subject, both Polish and foreign, and statistical analysis based on the World Bank data were used.

Results: The euro effect undoubtedly occurs, however it is difficult to clearly determine its size. It is diversified in terms of the sector. In addition, one can notice the diversified impact of the euro introduction on the trade of the monetary union individual members, which depends on several factors, i.e. the moment the introduction of the euro, market size, economic openness of countries and the specialization, and the fragmentation of production of individual economies.
\end{abstract}

Keywords: euro; Eurozone; trade; euro effect

JEL: F14; F15 